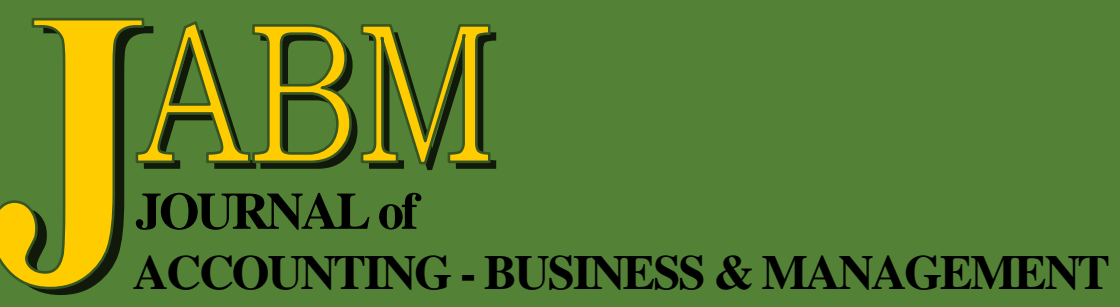

Individualism versus Collectivism Orientation as Moderator between Co-Workers' Social Support and Work to Family Enrichment

Aneel Kumar, Khalil Ahmed Channa and Muhammad Waqas Maharvi

Strategic Alliances in Knowledge-Intensive Industries: An Integrated View

Yongliang Stanley Han and Xiang Liu

Strategic Investment Decisions: An Empirical Study of Power Sector in India

Santosh Phulpagar, Koilakuntla Maddulety, Srinath Jagannathan, and Shalini Kalia

The Design of a Web-Based Program for Reporting Incomes Tax Article 21 for Civil Servants

Damayanti and Tri Sandhika Jaya

The Deceitfulness of Sticky Costs on Banking Systems

César Vela-Beltrán-del-Río and Luis Felipe Llanos Reynoso 
Journal of Accounting - Business \& Management vol. 25 no. 2 (2018) 50-60

\title{
The Design of a Web-Based Program for Reporting Incomes Tax Article 21 for Civil Servants
}

\author{
Damayanti* \\ Tri Sandhika Jayat
}

\begin{abstract}
This research aimed to created a model program of tax retun (SPT) of income tax article 21 especially for civil servants. The method of data collection used in this researchr are field research through the face-to-face interview and observation in district TBS, Inspectorate of Bandar Lampung and Politeknik Negeri Lampung. The result from this research is the formation of modelling of program SPT income tax article 21 special for civil servants which withholding tax slip both final and non final can be printed online. This program is made to resolved the problem especially for civil servants who only received the withholding tax slip from their regular income. A withholding tax slip that can be printed later is a form 1721 A2 (non final) which is obtained once a year, while a form 1721-VII (final) will be obtained whenever employee received their income.
\end{abstract}

Keywords: model, web-based withholding tax slip of tax article 21, civil servants.

\section{INTRODUCTION}

Any individual taxpayer either working in government or non-government agency must be familiar with the term of personal income tax $(\mathrm{PPh})$ article 21, that always be printed in the salary slip from the office accountant. PPh article 21 is an income tax that connect with a job, service, and activities carried out by an individual resident taxpayer (Resmi, 2014). Damayanti and Eksa (2008) was mentioned one of the tax collector of PPh article 21 for an income that come from APBD/APBN funds is a government treasurer. Beside collecting PPh article 21, the treasurer also have an obligation to make a withholding tax slip of $\mathrm{PPh}$ article 21.

The problems that happen in reality is the employee just received the withholding tax slip of regular income and the regular allowance that contain in the form 1721 A2 (non final tax), while for the other incomes such as lecturer/teacher certification, performance allowance/renumeration and honorarium from other activities although the tax already colectted by the collector but, the collector did not make the withholding tax slip which should be in the form 1721-VII (final tax) for the employee. The impact of not receiving the withholding tax slip of other income except salary and regular allowance is, make the employee as the individual taxpayer not reporting their income except that already printed in the withholding tax slip form 1721 A2, this is causing the individual annual tax return (SPT) that was reported by the employee is not relevant. To reduce and prevent the problem that was explained above, in this research writer wishing to develop a program that can calculate $\mathrm{PPh}$ article 21 especially for civil cervants that based on the employee payroll application program

\footnotetext{
* Lecturer, Department of Tax Accounting, Politeknik Negeri Lampung. E-mail: damayanti@ polinela.ac.id.

† Lecturer, Department of Informatic Management, Politeknik Negeri Lampung. E-mail: sandi@polinela.ac.id.
} 
owned by the Treasurer. In the Table 1 and Picture 1 can be seen the different between program that being used and the model program that will be created in this research in connection with the process of making the withholding tax slip of PPh article 21 tax return (SPT), so the benefit from this research can be seen:

Table 1

The Different between Program that being Used and program that will be Created

\begin{tabular}{|c|c|c|}
\hline No. & Program that being Used & Program that will be Created \\
\hline 1. & $\begin{array}{l}\text { The treasurer must re-input the } \\
\text { income that employee received } \\
\text { and the PPh Article } 21 \text { that } \\
\text { treasurer collected. }\end{array}$ & $\begin{array}{l}\text { The treasurer no need to re-input the } \\
\text { income that employee received, but just } \\
\text { need to choose what they want to print } \\
\text { between payroll report, PPh Article } 21 \\
\text { periodic tax return, or withholding tax slip. }\end{array}$ \\
\hline 2. & $\begin{array}{l}\text { The time that being used for } \\
\text { inputing the tax return report is } \\
\text { based on the amount of the } \\
\text { employees. }\end{array}$ & $\begin{array}{l}\text { No need to take more time to input the tax } \\
\text { return report, even though there are so } \\
\text { many employee. }\end{array}$ \\
\hline
\end{tabular}

According to Sianturi (2013), the result of this study is the imposition of tariffs for all the components of calculation and reporting of PPh Article 21 used by DPPKAD Karawang District has been in accordance with the applicable laws and regulations, except the imposition of tarrifs on THT (ENT) contributions. Errors on the implementation of THT (ENT) contribution tariff make the calculation of PPh Article 21 over the civil servant (PNS) income become incorrect and the reporting of $\mathrm{PPh}$ Article 21 that is done by each civil servant to the KPP Pratama Karawang District, the problem in fulfillment of tax obligations of PPh Article 21 on income of civil servants in DPPKAD Karawang District is the lack knowledge of civil servants on tax regulations, especially about $\mathrm{PPh}$ article 21.

The result of Rochman analysis (2010), shows that the calculation performed by Diskes Bangkalan District there is a significant difference in the amount of tax payable annually or monthly, this is because of the calculation are not in accordance with the tax regulation and laws, while for the implementations of depositing and reporting $\mathrm{PPh}$ article 21 there is no significant difference and is in accordance with the regulation of general of taxation (regulation of minister No. 15/PJ/2006).

Damayanti (2006) and Damayanti (2008) stated that there is a part of the income earned by the employee even though the $\mathrm{PPh}$ article 21 collected by the company/treasurer but the tax is not reported in withholding tax slip (form 1721 A1 and $1721 \mathrm{~A} 2$ ) such as income from other activities/commitee, overtime pay and allowance, that is being reported at withholding tax slip is just an income from salary and regular allowance, as well said by Damayanti et al. (2014) without giving the withholding tax slip, if the income earned by the employee is reported in the annualy tax return (SPT) of individually taxpayer can resulted in tax underpayment, so taxpayer reluctant to add up their other income with their existing income that has the withholding tax slip.

The result of this study concluded, that because of the types of the income earned by each employee is different and with many emloyee must be inputted for the tax report as well as lack of knowledge of the treasurer about the tax regulation and laws which is often to be modificate making the error in tax deduction and withholding tax slip will have an effect in the annual tax return report (SPT) of the individual 
taxpayer, so there must be a payroll program that directly connect with the process of making the annual tax return PPh article 21 and a withholding tax slip that can be printed without having to re-input the data.

The purpose of this research is to form a model of SPT PPh article 21 program, which the data can be processed from the moment the Treasurer input the employee regular income as usual every month. So, with this research can help the country to reduce the loss of a potencial tax income especially from $\mathrm{PPh}$ article 21.

\section{LITERATURE REVIEW}

\subsection{Civil Servants}

The definition of civil servants in article 1 section 3 of Law number 5 year 2014 about civil servants officer (ASN), is an Indonesian citizen who fulfills certain conditions, is appointed as a civil servants officer (ASN) on a regular basis by an official staffing officer to occupy a position in the government. ASN employee in article 2 is a civil servant and a government employee with a work agreement that appointed by an official staffing officer and entrusted with duties in government position or entrusted with other state duties and paid based on legislation (Kemenhumham, 2014).

\subsection{Incomes and Tax Income (PPh) Article 21}

The definition of incomes in article 4 section 1 of Law number 7 year 1983 about tax income as amended by Law number 36 year 2008, is any additional economic capabilities received or obtained by Taxpayers, both from Indonesia or overseas, which can be used for consumption or to increase the Taxpayers wealth, by whatever name and form (Kemenhumham, 2008).

The definition of tax in article 1 section 1 of Law number 6 year 1983 about General Requirements and Tax Procedure as amended by Law number 16 year 2009, is a mandatory contributions to the state owed by an individual taxpayer or institution that is compelling based on the Law, by not getting direct reward and used for state purpose for the prosperity of the people (Kemenhumham, 2009).

Tax income (PPh) article 21 is tax that withheld on income in the form of salary, honorarium, allowance, and other allowance by whatever it's name that received by a domestic individual taxpayer in connection with work, services, or activities as stated in article 21 Law Income Tax (Damayanti \& Eksa, 2008, p. 44).

Taxholder are parties that did the deductions, deposits, and reporting of Tax Income article 21 (Damayanti \& Eksa, 2008, p. 44). Parties who obliged to did the deductions, deposits, and reporting Tax Income article 21/26 are employer, treasurer, government, pension funds, institution, company, and organizer of activities (Resmi, 2014, p. 179).

Tax income article 21 that owed on fixed and regular income every month which is come from APBN or APBD is borne by the government expense of APBN or APBD. Fixed and regular income includes:

a). State officials, for (1) salary and other regular allowance every month; or (2) fixed remuneration based on the provisions of the Law;

b). Civil Servant (PNS), Indonesian State Army (TNI) members, and Indonesian Police (POLRI) members, for salary and other regular allowance every month based on the provisions of the Law; and

c). Pensionary, for pension and other regular allowance every month based on the provisions of the Law. 
While Tax Income article 21 owed on income other than the income explained in article 2 section (2) in the form of honorarium or other remuneration by whatever the name which become an APBN or APBD expense, will be deducted by the goverment treasurer that paid the honorarium or other remuneration (Kemenhumham, 2010).

\subsection{Taxholder Obligation}

In the Directorate General of Tax Regulation Number PER-16/PJ/2016 tanggal 29 September 2016 (Direktorat Jenderal Pajak/DJP, 2016) 23 section (1), said that Taxholder must give the annual Tax Slip of Tax Income article 21 to permanent employee, including monthly pension recipient, by using a form that determined by Directorate General of Tax within 1 (one) month after the calendar year ends. Meanwhile, section (2) mentioned: if the permanent employee stop working or retired on calendar year, then tax slip as mentioned in section (1) given by the employer at the latest 1 month after the employee stop working or retired and section (3) tax slip must be given to other than permanent employee and pension recipient every time the deduction done.

Income payment that must be deducted by Tax Income article 21 by the government treasurer (DJP, 2016) such as salary payment, allowance, honorarium, wage, meal allowance, and other payment (except the payment of the official travel expense), both for employees or not employee.

\subsection{Flowchart}

Flowchart is a chart that has a flow that describes the steps to solve a problem (Jaya \& Sahlinal, 2017). The purpose creating a flowchart are: (a) describe a problem solving steps, (b) simply, decomposed, neat, and clear, (c) using a standard symbols.

Flowchart used in the process of preparation of developing a web-based program for reporting Tax Income article 21 for civil servant that has been done in the first year. The symbols used in the flowchart (Jaya \& Sahlinal, 2017) can be seen in Table 2 below:

Insert Table 2 here.

\subsection{Data Flow Diagram (DFD)}

Data Flow Diagram (DFD) is a data logic model or process that is created to describe: where the data come from, where the data destination out of the system, where the data is stored, what processes used to produce the data, the interaction between the data stored, and the processes imposed on the data (Afyenni, 2014). Basically, DFD described in the form of hierarchy, the first one called as DFD level 0 which describe the system as a whole, meanwhile the other DFD's is a smoothing system from the previous DFD.

DFD using four kind of symbol that is: all the symbol used in CD plus one symbol to symbolize data storage. There are two technique to symbolize a symbol DFD commonly used: the first one is Gane and Sarson, the second is Yourdon and De Marco. The difference between the two techniques are the emblem from the symbol used. Gane and Sarson use a rectangular symbol with a blunt upper end to describe a process and use a rectangular symbol with the right side open to represent the data storage. Yourdon and De Marco use a circle to represent a process and use a parallel lines to describe the data storage. Meanwhile, the symbol of entity external and data flow the two techniques use the same symbol that is: rectangular to describe entity external and an arrow to describe the data flow (Afyenni, 2014). 
Table 2

The Symbols in the Flowchart

Usability
Flow direction symbols:

\section{Input/output symbols:}

1.

2.

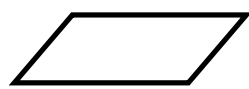

3.

4.

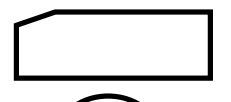

6.
Input/output symbol, it indicates input or output process

Punched card symbol, it indicates the data is input from the card or the output written on the card

Magnetic tape symbol, is indicated the data input and will be stored on magnetic tape

Disk storage symbol, it indicate the data input and will be saved in the disk

Document symbol, print output in the form of document (using printer)

Display symbol, display the output in the monitor 


\section{RESEARCH METHOD}

This research will be done at Politeknik Negeri Lampung and collaborate with Local Government of Bandar Lampung City (at South Teluk Betung Districts and Inspectorate of Bandar Lampung). The research location were selected by using a purposive judgment considering to get a complete picture about the employee and their salary data from educational institution and government agency which is useful to analizyng the many kinds of income that earned by the employee and the calculation of $\mathrm{PPh}$ article 21 which affect the application to be generated.

The method used is action research method, this method is to review the program that being used and then based on the result of the review can develop a new program. The collection data method used is:

1. Literature research, to collect the secondary data in the form of legislation document, regulation document, books along with any related articles, and

2. Field research, to collect the primary data through:

a). Face-to-face interview, is the researcher conduct a direct interview with the treasurer of Politeknik Negeri Lampung, head of financial division payroll division of Badan Pengelolaan Keuangan and Aset Daerah (BPKAD) Bandar Lampung City, head of financial division of Inspectorate of Bandar Lampung City and head of financial division of south Teluk Betung district about payroll system that being used;

b). Observation, is the researcher conduct a direct observation of the object and target which is will be inspected, in order to collect the data and other information.

\section{RESULT AND DISCUSSION}

\subsection{Working System Analysis}

The payroll system in the local government of Bandar Lampung city is divided into two authorization of payroll/reporting, for the payroll regular income of permanent employee the input process is under the authority of BPKAD, while for the payroll non regular income that come from other activities and honorarium for nonpermanent employee (honorary) is under the authority of each institution. In practice the form 1721 A2 were manually input (even though using a computer as a media) by the institution Treasurer based on the payroll slip that were received from BPKAD, but for non regular income such as honorarium from other activities were made by the institution Treasurer. Although the tax is already collected for this kind of income but there is no withholding tax slip given to the employee.

Based on the salary reports that have been made by BPKAD, the payroll Treasurer of institution will re-input the data with the intention to make a payroll slip that will be approved by the head of institution, printed and distributed to each employee. While for the purpose of annual tax return, expense treasurer as the treasurer that in charge to make a withholding tax slip will re-input manually the form 1721 A2 of withholding tax slip based on the salary reports from BPKAD before it will be distributed to each employee.

In Politeknik Negeri Lampung, althought the treasurer has been using a webbased payroll system program that is called "gaji pegawai pusat (GPP)", but in this program there is no option to print the withholding tax slip of Tax Income article 21 for employee and for other income beside salary is also still need to manually input by the financial administration separately (using microsoft excel). For a withholding tax 
slip form 1721 A2 is also manually input, and there is no withholding tax slip for other income such as lecturer certification and other activities honorarium.

\subsection{Design Analysis of the Proposed Model}

Based on the salary and other ongoing income input system, model of the salary system that will be generate to complement the system before. By the mean to complement is to be able to print a withholding tax slip of Tax Income article 21 by the financial administration, head of agency/institute, and the employee themself.

\subsubsection{Context diagram modeling of the proposed payroll system.}

\section{Picture 1}

Flow Chart of the Proposed Payroll System

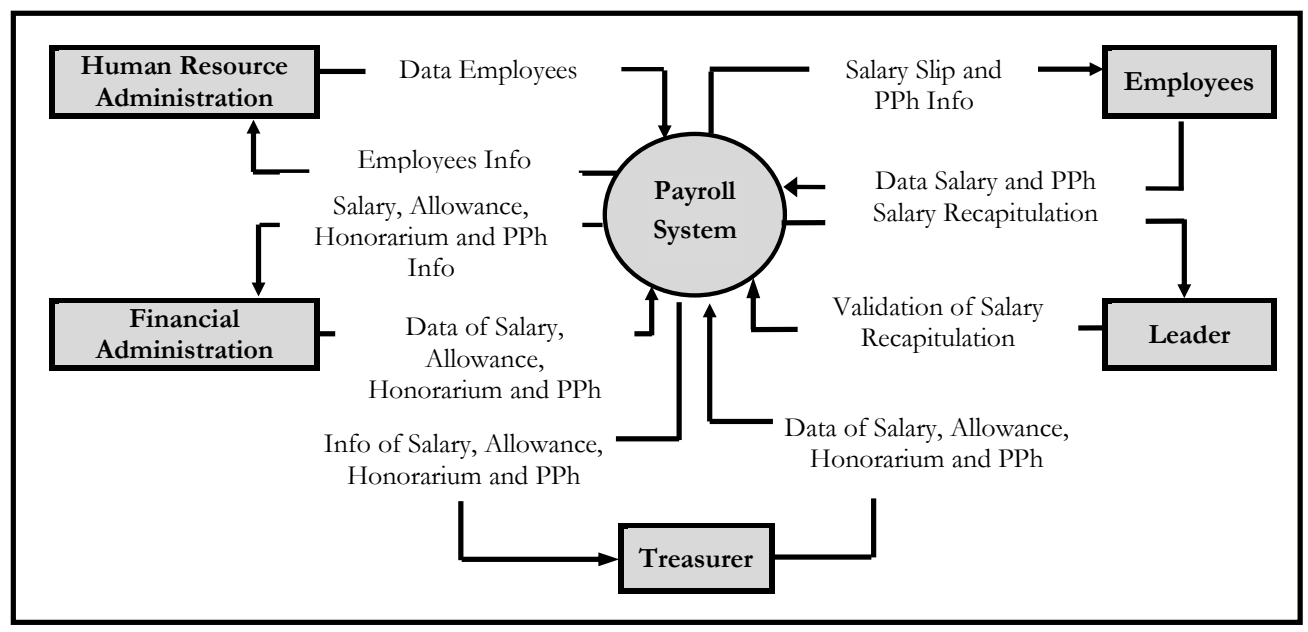

Based on the Picture 1, after all the employee data and all the income either the regular or non regular income, honorarium from other activities, performance allowance (including lecturer certification) and the honorary income inputted all in that application and later will be processed, then the salary data, slip and the withholding tax slip can be printed online without need to re-input the data manually when needed.

\subsubsection{Flow chart of the inputted data employee}

The inputted data employee is according to which kind of the employee, both permanent employee and non permanent employee. Definition of permanent employee according to the regulation of general of taxation number: PER-16/PJ/2016, 29 September 2016 is an employee who receive or gain an income in certain amount regulary, included council commisioner and supervisory board members, along with an employee who work based on a contract in a certain period of time and receive or gain an income in certain amount regulary. Menawhile, the definition of non permanent employee/outsourcing employee is an employee who only receive an income if the employee is working, based on the amount of the day they spend and the amount of product they made or done the job asked by their job giver (DJP, 2016).

Flow chart of the inputted data employee which is later will be input by financial administrator where the data will be given by the human resource administrator, displayed in Picture 2 below: 
Picture 2

Flow Chart of the Inputted Data Employee

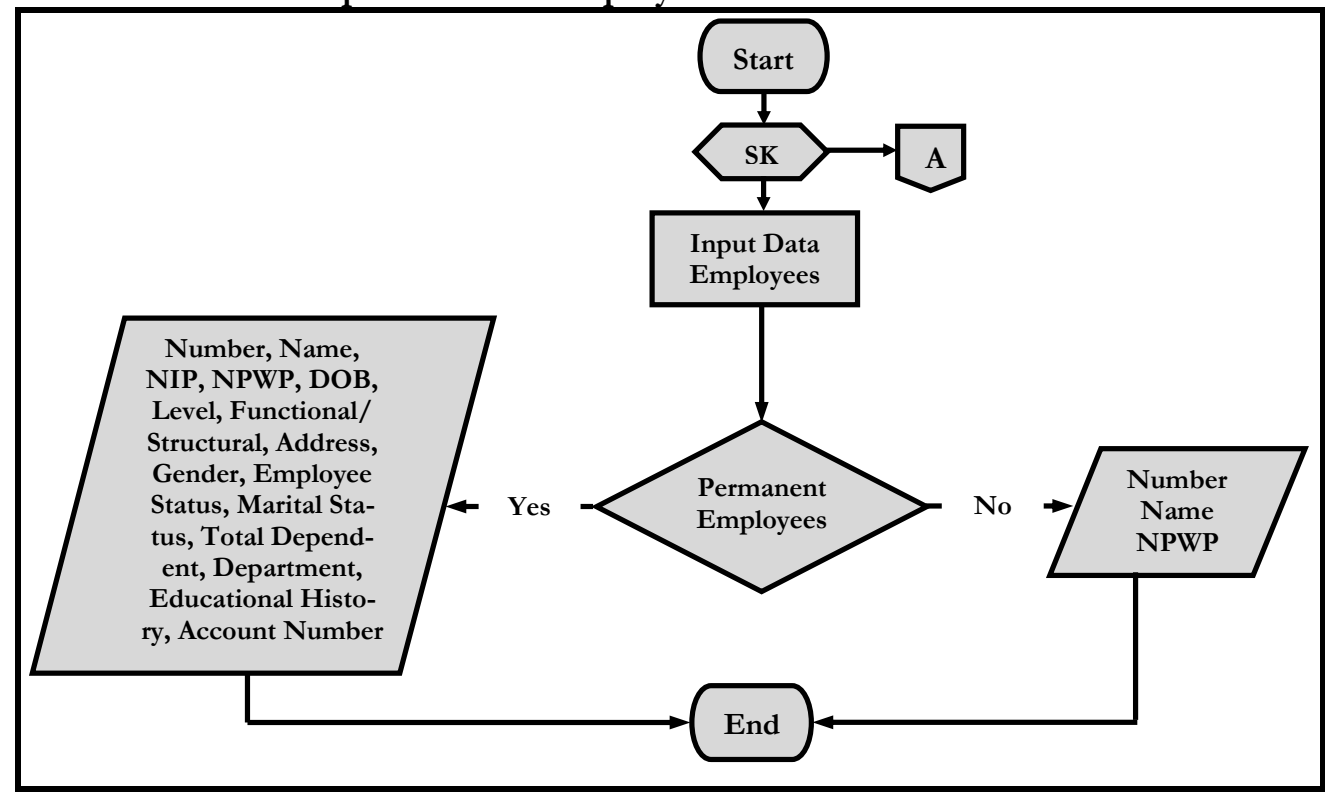

4.2.3. Flow chart of the inputted data salary income, honorarium, performance allowance (lecturer certification) and honorary salary

The income that civil servant earned consist of final income and non final income. Final income is an income which is the income tax PPh can not be a part of tax credit or non deductable in the end of the tax period. Income except salary which is earned by civil servants is charged by final income tax $(\mathrm{PPh})$, the final income is such as lecturer/teacher certification allowance, performance allowance/renumeration allowance, and honorarium from other activities financed by the APBN/APBD funds. Employee can print the withholding tax slip of PPh article 21 final (form 1721-VII) by themself and everytime they earn an income, while for the withholding tax slip of PPh article 21 non final (1721 A2) can be printed by the employee in every end of the tax period. For the non final income, the tax payable can be credited or can be the deduction of the tax payable which is reported in the individual annual tax return.

The display of flow chart of the inputted data salary, honorarium, performance allowance (lecturer certification) and honorary salary can be seen in Picture 3 below:

Insert Picture 3 here.

\section{CONCLUSIONS AND RECOMMENDATION}

\subsection{Conclusions}

The designed model can help to resolve the problem of the Treasurer in Indonesia. Basically, through this designed model the Treasurer no need to re-input the income data if they want to make a withholding tax slip and give it to the employee and the employee also can access the site to see the withholding tax slip from all of the income they receive during certain tax period, so there is no more mistake or error in the report of individual annual tax return. The last result of this program is, financial admininstration, the head of the agency/institute, as well the employee can print their withholding tax slip of $\mathrm{PPh}$ article 21 either final or non final income online by themself. 
Picture 3

Flow Chart of the Inputted Data Salary, Honorarium, Performance Allowance (Lecturer Certification) and Honorary Salary

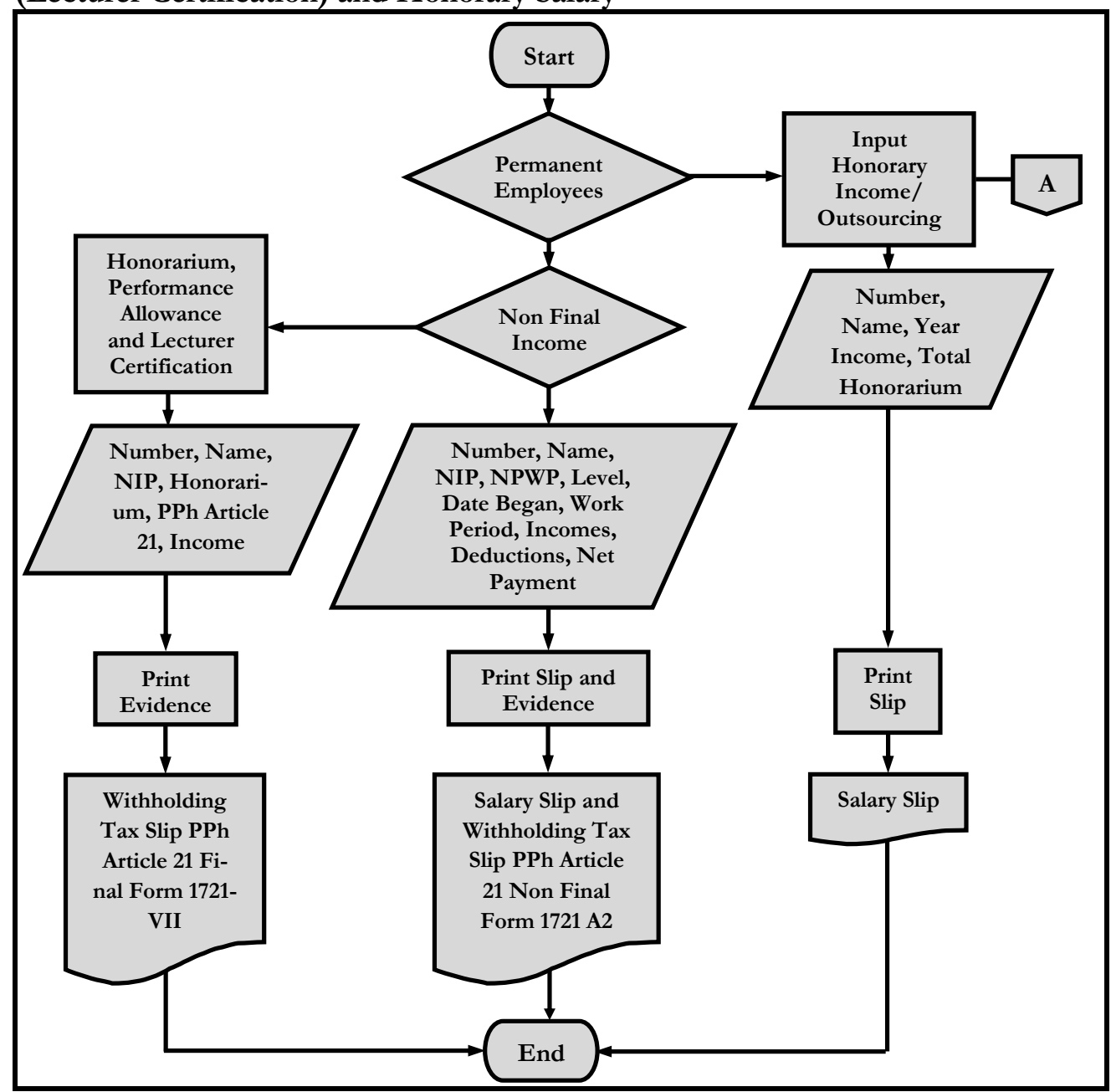

\subsection{Recommendation}

The recommendation for the next research in manufacturing the application of payroll system is to focus on the tax and law regulations about non-taxable income which is given by the government for individual tax payer which is often to change or modified every year to re-adjust with the economic level of society.

\section{REFERENCE}

Afyenni, R. (2014, April). Perancangan data flow diagram untuk sistem informasi sekolah (studi kasus pada SMA Pembangunan Laboratorium UNP). Teknoif Journal, 2(1), 35-39. Retrieved January 16, 2017, from https:/ / journal.itp.ac.id/index.php/tinformatika/article/download/184/181+ $\& \mathrm{~cd}=1 \& \mathrm{hl}=\mathrm{id} \& \mathrm{ct}=\mathrm{clnk} \& \mathrm{gl}=\mathrm{id}$.

Damayanti \& Eksa, R. (2008). Pajak. Jakarta: Wineka Media. 
Damayanti (2006). Pelatiban penghitungan pajak dan pengisian SPT (Tech. Rep. No.: 14/NO7.3/PM/2006). Report devotion to the community which is registered on KKI. Bandar Lampung: Politeknik Negeri Lampung.

Damayanti (2008). Pelatihan perpajakan dan aplikasi pengisian SPT tabunan dan SPT masa (Tech. Rep. KUP, PPh pasal 21, 22, 23 dan 26). Report devotion to the community which is registered on KKI. Bandar Lampung: Politeknik Negeri Lampung.

Damayanti, Rusmianto, Irawan, Pentiana, D., \& Wijaya, L. R. P. (2014, April 14). Pelatihan teknis pajak penghasilan (PPh) pasal 21 dan PPh orang pribadi (Tech. Rep. No. 024/PL15.8/PM/2014). Report devotion to the community which is registered on KKI. Bandar Lampung: Politeknik Negeri Lampung.

Direktorat Jenderal Pajak Kemenkeu RI/DJP (2016). Bendahara mahir pajak. Tim Penyusun Direktorat Peraturan Perpajakan II Jakarta. Retrieved March 4, 2017, from http://www.pajak.go.id/content/buku-bendahara-mahir-pajak-edisi-revisi2016

Direktorat Jenderal Pajak Kemenkeu RI/DJP (2016). Peraturan Dirjen Pajak nomor: PER16/PJ/2016 tanggal 29 September 2016 tentang pedoman teknis tata cara pemotongan, penyetoran dan pelaporan pajak. penghasilan pasal 21 dan/atau pajak. penghasilan pasal 26 sehubungan dengan pekerjaan, jasa, dan kegiatan orang pribadi. Tim Penyusun Direktorat Peraturan Perpajakan II. Jakarta. Retrieved March 4, 2016, from http://www.pajak.go.id/sites/ default/files/info-pajak/PER16-PJ-2016.pdf.

Jaya, T.S., \& Sahlinal, D. (2017). Perancangan Kantor Digital Berbasis Framework dengan Metode Waterfall pada Politeknik Negeri Lampung, J. Inform. J. Pengemb. IT, vol 2, no. 2, page 14-17, 2017. Retrieved July 7,2016, from http://ejournal.poltektegal.ac.id/index.php/informatika/article/view/518.

Kementerian Hukum dan Hak Asasi Manusia/Kemenhumham (2008). Undang-Undang nomor 7 tahun 1983 tentang Pajak. Penghasilan sebagaimana telah diubah dengan UndangUndang nomor 36 tahun 2008. Retrieved March 4,2016, from http://www.jdih.kemenkeu.go.id/fullText/2008/36TAHUN2008UU.htm.

Kementerian Hukum dan Hak Asasi Manusia/Kemenhumham (2009). Undang-Undang nomor 6 tabun 1983 tentang ketentuan umum dan tata cara perpajakan sebagaimana telah diubah terakhir dengan Undang-Undang Nomor 16 tabun 2009. Retrieved March 4, 2016, from http://www.jdih.kemenkeu.go.id/fullText/2009/16TAHUN2009 UU.htm.

Kementerian Hukum dan Hak Asasi Manusia/Kemenhumham (2010). Peraturan pemerintah RI nomor 80 tabun 2010 tentang tarif pemotongan dan pengenaan PPh pasal 21 atas penghasilan atau anggaran pendapatan dan belanja daerah. Retrieved March 4, 2016, from http://www.ortax.org/ortax/?mod=aturan\&page=show\&id $=14533$.

Kementerian Hukum dan Hak Asasi Manusia/Kemenhumham (2014). Undang-Undang RI. Nomor 5 Tabun 2014 tentang Aparatur Sipil Negara. Retrieved March 4, 2016, from http://www.jdih.kemenkeu.go.id/ fullText/2014/5TAHUN2014UU.HTM Resmi, S. (2014). Perpajakan: Teori dan kasus I (8th ed.). Jakarta: Salemba Empat.

Rochman, Y. (2010). Analisis pelaksanaan pemotongan, penyetoran, dan pelaporan pajak penghasilan, pasal 21 atas pegawai tetap pada Dinas Kesehatan Kabupaten Bangkalan (studi kasus bulan September 2006). Undergraduate thesis, Accounting Department, Economy Faculty, Airlangga University, Surabaya. Retrieved August 26, 2017, from http://repository.unair.ac.id/4598/1/gdlhub-gdl-s12011-rochmanyah-15849-a22010-k.pdf. 
Sianturi, P. J. U. (2013). Prosedur penghitungan dan pelaporan pajak penghasilan pasal 21 atas gaji PNS pada Dinas Pendapatan Pengelolaan Keuangan dan Aset Daerah (DPPKAD) Kabupaten Karawang. Master' Thesis Accounting Department, Economy Faculty, Christian Maranatha University, Bandung. Retrieved August 26, 2017, from http://repository.maranatha.edu/id/eprint/7573. 